http://zoobank.org/References/72911E95-9ACC-42D2-A7CF-A6CD66B0DACD

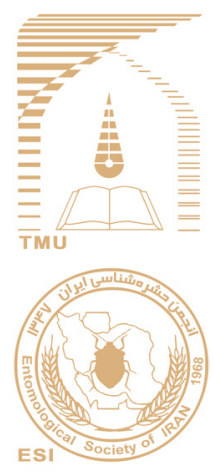

\title{
New records of two cuckoo wasp species (Hymenoptera: Chrysididae) from Iran
}

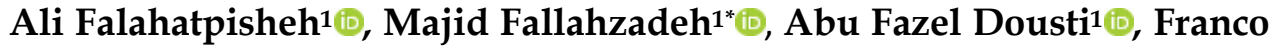 \\ Strumia2 ${ }^{(i)}$ \& Nazila Saghaei ${ }^{3}$ (i) \\ 1 Department of Entomology, Jahrom Branch, Islamic Azad University, Jahrom, Iran. afp12250@gmail.com; \\ mfalahm@yahoo.com; fdousti@yahoo.com \\ 2 Physics Department, Pisa University, Largo Pontecorvo, 3, 56127, Pisa, Italy. franco.strumia@unipi.it \\ 3 Department of Entomology, Marodasht Branch, Islamic Azad University, Marvdasht, Iran. nazila_saghaei@yahoo.com
}

ABSTRACT. Two cuckoo wasp species (Hymenoptera: Chrysididae), Trichrysis lacerta (Semenov, 1954) from the subfamily Chrysidinae, and Cleptes striatipleuris Rosa, Forshage, Paukkunen \& Soon, 2015 from the subfamily Cleptinae, are newly documented for the Iranian fauna. The specimens were collected using Malaise traps in the Fars Province, south of Iran during 2015-

Received:

17 November, 2020

Accepted:

02 January, 2021

Published:

09 January, 2021

Subject Editor:

Afrouz Farhad 2016. Notes about taxonomy, relevant references as well as geographical distribution of both species are given. The total number of Iranian Trichrysis and Cleptes currently increased to four and three species, respectively.

Key words: Cuckoo wasps, Chrysidinae, Cleptinae, Hymenoptera, new records

Citation: Falahatpisheh, A., Fallahzadeh, M., Dousti, A.F., Strumia, F. \& Saghaei, N. (2021) New records of two cuckoo wasp species (Hymenoptera: Chrysididae) from Iran. Journal of Insect Biodiversity and Systematics, 7 (2), 137-143.

\section{Introduction}

The Chrysididae, cuckoo wasps, are a family of the Aculeata or stinging wasps with about 3,000 species found worldwide (Kimsey \& Bohart, 1991; Aguiar et al., 2013). Studies of the Iranian cuckoo wasp fauna were limited until the two last decades. Rosa et al. (2013) catalogued 184 species in 20 genera of Chrysididae in the first checklist for Iran. Later, other authors (e.g. Rosa \& Lotfalizadeh, 2013; Torabipour et al., 2013a, 2013b; Strumia \& Fallahzadeh, 2015; 2016; Strumia et al., 2016a; 2016b; Farhad et al., 2015, 2016, 2017, 2018, 2019; Farzaneh et al., 2017; Iranmanesh et al., 2017; Rosa et al., 2017; Falahatpisheh et al., 2019, 2020; Rosa, 2020), added many more species and genera, and as a result the number of known taxa from the country has considerably increased to about 320 species and subspecies.

The current paper aims to provide information on the newly discovered cuckoo wasps in the Fars Province, and thus to make an additional contribution to the knowledge of the Iranian wasp fauna.

\footnotetext{
Corresponding author: Majid Fallahzadeh, E-mail: mfalahm@yahoo.com

Copyright $\odot$ 2021, Falahatpisheh et al. This is an open access article distributed under the terms of the Creative Commons Attribution License (CC BY 4.0), which permits unrestricted use, distribution, and reproduction in any medium, provided the original author and source are credited.
} 


\section{Material and methods}

Surveys in 2015-2017 using Malaise traps in different localities of the Fars Province in southern Iran resulted in finding two species of cuckoo wasp new for the country. The examined specimens in this study are deposited in the Department of Entomology, Jahrom Branch, Islamic Azad University, Jahrom, Iran (JIAU) and the Franco Strumia Collection, Pisa, Italy (FSC). Photos were taken using a Nikon 990 camera mounted on a Nikon SMZ-2T stereoscopic microscope, and were processed with Adobe Photoshop or Apple Preview software.

\section{Results}

Subfamily Chrysidinae Latreille, 1802

Tribe Chrysidini Latreille, 1802

Genus Trichrysis Lichtenstein, 1876

Trichrysis lacerta (Semenov, 1954)

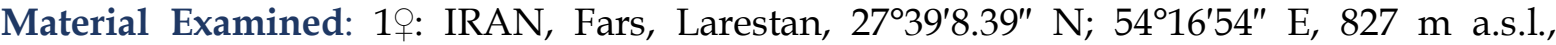
20.v.2015, Malaise trap in a mixed orange tree (Citrus spp) and palm date (Phoenix dactylifera L.) orchard, leg. A. Falahatpisheh; 1 ơ: Fars, Shiraz, 2959'6.65 " N; 52³9'38.5 " E, 1628 m. a. s. 1, 12.vi.2016, Malaise trap in a garden with a large number of fruit trees and ornamental plants including walnut, pomegranate (Punica granatum L.), pine (Pinus ssp.) and cypress trees (Cupressus sempervirens L.), leg. B. Jahromi.

Diagnosis: Body length $4.2-4.8 \mathrm{~mm}$; anal margin with straight or slightly concave intervals, the keel of the median tooth not very prominent; colour green to golden-green, base of T2 and T3 narrow dark blue; punctures on metasoma smaller than on mesosoma and fairly dense, punctation of T2 finer than on T1 and T3 (Fig. 1).

General distribution: Greece, Cyprus, Turkey, the Caucasus and Egypt (Kimsey \& Bohart 1991; Strumia, 2009) and Iran (new record).

Remarks: The genus Trichrysis, distributed worldwide, contains 36 described species, 11 of which are found in the Palaearctic region (Kimsey \& Bohart 1991; Linsenmaier 1994, 1997; Strumia, 2009; Madl \& Rosa, 2012; Rosa et al., 2016). The Mediterranean species of the genus were revised and keyed by Strumia (2009), while Rosa et al. (2016) revised the Chinese species. Only three species of the genus had been recorded from Iran before the present study: T. cyanea (Linnaeus, 1758), T. longispina (Mocsáry, 1912), and T. scioensis (Gribodo, 1879) (Pourrafei et al. 2011; Rosa et al., 2013; Strumia \& Fallahzadeh, 2015; Farhad et al., 2016; Farzaneh et al., 2017; Rosa, 2020). Our record of T. lacerta is the south-easternmost in its overall range. In this species space between teeth of T3 straight or slightly concave (see Strumia, 2009) (Fig. 1). According to Rosa et al. (2016) and Strumia \& Dawah (2019) specimens collected with Malaise traps or conserved in alcohol till they are completely dehydrated may change colours when they were prepared: blue metallic colour turns into dark blue, green turns into blue, yellow turns into greenish and red becomes more yellowish.

Subfamily Cleptinae Latreille, 1802

Genus Cleptes Latreille, 1802

Cleptes striatipleuris Rosa, Forshage, Paukkunen \& Soon, 2015

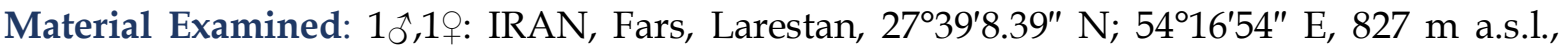
10.v.2015, Malaise trap in a mixed orange tree and palm date orchard, leg. A. Falahatpisheh. 

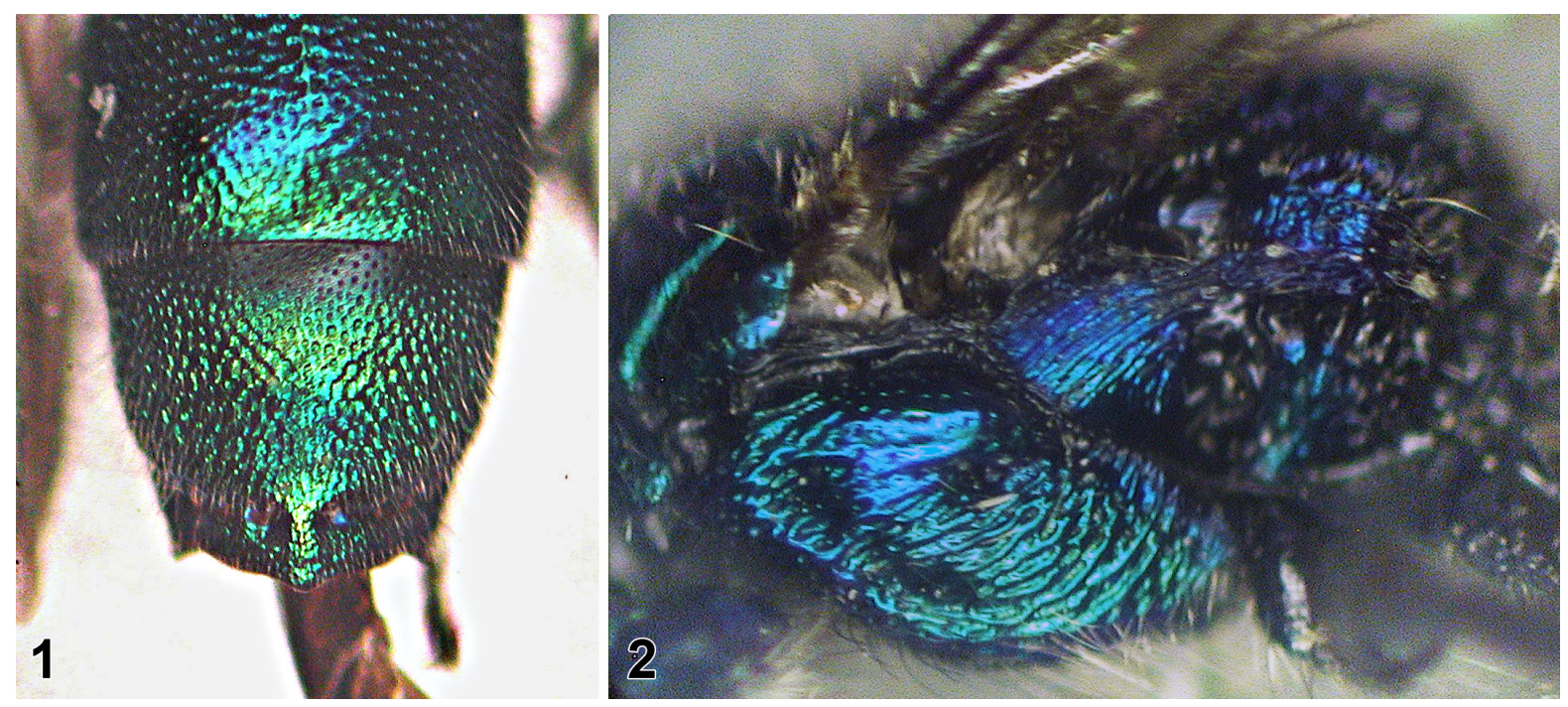

Figures 1-2. Cuckoo wasps; 1. Trichrysis lacerta (Semenov, 1954) $\odot$, tergite III in dorsal view; 2. Cleptes striatipleuris Rosa, Forshage, Paukkunen \& Soon, 2015 $\hat{\sigma}$, mesopleuron in lateral view.

General distribution: Caucasus, South-eastern Europe, Russia and USA (Rosa et al., 2015, 2019) and Iran (new record).

Remarks: Cleptes is a Holarctic genus of about 100 species, of which more than 71 are Palaearctic (Kimsey \& Bohart, 1991; Móczár 1997a, 1997b, 1998a, 1998b, 1998c, 2000a, 2000b, 2001, 2009; Rosa et al., 2015). So far, two species, C. splendidus (Fabricius, 1794) and C. semiauratus (Linnaeus, 1761) have been reported from Iran (Rosa et al., 2013; Strumia \& Fallahzadeh, 2015; Farzaneh et al., 2017). Our record of C. striatipleuris is the southeasternmost in its overall range.

This species differs from all known species of the Palaearctic region by the peculiar horizontally striated mesopleuron (Fig. 2).

\section{Discussion}

As a result of this paper, two cuckoo wasp species, Trichrysis lacerta and Cleptes striatipleuris have been recorded for the first time from Iran. Iran represents the south-easternmost record of both species. The total number of Iranian Trichrysis and Cleptes now increased to four and three species, respectively. Rosa et al. (2013) listed 184 species of Chrysididae from Iran. With addition results of the present paper and previous works (e.g. Torabipour et al., 2013a, 2013b; Strumia \& Fallahzadeh, 2015; 2016; Strumia et al., 2016a, 2016b; Farzaneh et al., 2017; Iranmanesh et al., 2017; Farhad et al., 2015, 2016, 2017, 2018, 2019; Falahatpisheh et al., 2019; Rosa, 2020), the number of cuckoo wasps known from Iran is raised to about 322 species and subspecies. A comparison of this species number with those recorded for adjacent areas such as Turkey with 410 species (Özbek \& Strumia, 2018), Russia with 340 species (Rosa et al., 2019), and the Arabian Peninsula with 124 species (Strumia, 2008, 2014; Strumia \& Dawah, 2010, 2012, 2019; Rosa et al., 2020) reveals that the fauna of these wasps in Iran is moderately known. Given the extension of Iran in the Palaearctic region, and its closeness to the Afrotropical, Oriental and Caucasus regions, one can certainly expect additional species not yet found in Iran. 


\section{Acknowledgments}

This research was supported by Department of Entomology, Jahrom Branch, Islamic Azad University, Jahrom, Iran and the Physics Department of Pisa University, Italy.

\section{Conflict of Interests}

The authors declare that there is no conflict of interest regarding the publication of this paper.

\section{ORCID}

Ali Falahatpisheh: https:/ / orcid.org/0000-0002-8128-5348

Majid Fallahzadeh: https:/ / orcid.org/0000-0001-6609-0043

Abu Fazel Dousti: https:// orcid.org/0000-0003-4062-358X

Franco Strumia: https:// orcid.org/0000-0002-8496-7790

Nazila Saghaei: https:// orcid.org/0000-0002-1108-5447

\section{References}

Aguiar, A., Deans A., Engel, M., Forshage, M., Huber, J., Jennings, J., Johnson, N., Lelej, A., Longino, J., Lohrman, V., Mikó, I., Ohl, M., Ramusen, C., Taeger, A. \& Ki Yu, D. (2013) Order Hymenoptera, pp. 51-62. In: Zhang, Z. Q. (ed.) Animal Biodiversity: An Outline of Higher-level Classification and Survey of Taxonomic Richness (Addenda 2013). Zootaxa, 3703, pp. 1-82.

https://doi.org/10.11646/zootaxa.3703.1.12

Falahatpisheh, A., Fallahzadeh, M., Dousti, A. F., Strumia, F. \& Saghaei, N. (2019) A further contribution to the fauna of Iranian Elampini (Hymenoptera: Chrysididae, Chrysidinae). Journal of Entomological Research, 11 (1), 1-9.

Falahatpisheh, A., Fallahzadeh, M., Dousti, A. F., Strumia, F. \& Saghaei, N. (2020) A contribution to the knowledge of the genus Chrysis (Hymenoptera: Chrysididae) in Fars province, with six new records for Iranian fauna. Journal of Entomological Research, in press.

Farhad, A., Rosa, P. \& Talebi, A. A. (2018) Additions to the fauna of Iranian Elampini (Hymenoptera: Chrysididae, Chrysidinae), with key to species and taxonomic notes. Journal of Crop Protection, 7 (2), 191-206.

Fahrad, A., Rosa, P., Talebi, A. \& Ameri, A. (2015) The genus Chrysis (Hymenoptera: Chrysididae) in Hormozgan province of Iran, with four new records for Iranian fauna. Entomofauna, 36, 33-48.

Farhad, A., Rosa, P., Talebi, A. A., Fathipour, Y., \& Hajiqanbar, H. (2019) Two new species of Chrysis Linnaeus (Hymenoptera, Chrysididae) from Iran. Journal of Asia-Pacific Entomology, 22 (4), 10051012. https://doi.org/10.1016/j.aspen.2019.08.011

Farhad, A., Talebi, A., Rosa, P., Fathipour, Y. \& Hajiqanbar, H. (2016) Contribution to the knowledge of the Chrysididae (Hymenoptera, Aculeata) in the south of Iran, with nine new records. Turkish Journal of Zoology, 40, 1-13. https://doi.org/10.3906/zoo-1502-6

Farhad, A., Talebi, A.A., Fathipour, Y., Hajiqanbar, H. \& Strumia, F. (2017) The genus Holopyga (Hymenoptera: Chrysididae) in Iran, with five new records. Journal of Agricultural Sciences and Technology, 19, 877-888.

Farzaneh, F.S., Saghaei, N., Asadi, R. \& Strumia, F. (2017) A contribution to the fauna of cuckoo wasps (Hymenoptera, Chrysididae) in southern Iran. Entomofauna, 38 (23), 493-504.

Iranmanesh, S., Strumia, F., Madjdzadeh, S.M., Purrezaali, M. \& Lashkari, M.R. (2017) Fauna and species richness of chrysidid wasps (Hymenoptera: Chrysididae) in Mountains of Kerman province, south-east Iran. Journal of Insect Biodiversity and Systematics, 3 (4), 93-107. 
Kimsey, L.S. \& Bohart, R.M. (1991 ["1990"]) The Chrysidid wasps of the world. Oxford Science Publications, Oxford, New York, 652 pp.

Linsenmaier, W. (1994) The Chrysididae of the Arabian Peninsula (Insecta: Hymenoptera). Fauna of Saudi Arabia, 14, 145-206.

Linsenmaier, W. (1997) Altes und Neues von den Chrysididen (Hymenoptera, Chrysididae). Entomofauna, 18, 245-300.

Madl, M. \& Rosa, P. (2012) A Catalogue of the Chrysididae (Hymenoptera: Chrysidoidea) of the Ethiopian Region excluding Malagasy Subregion. Linzer biologische Beiträge, 44 (1), 5-169.

Móczár, L. (1997a) Revision of the Cleptes nitidulus group of the world (Hymenoptera, Chrysididae, Cleptinae). Entomofauna, 18 (3), 25-44.

Móczár, L. (1997b) Revision of Cleptes (Leiocleptes) species of the world (Hymenoptera: Chrysididae, Cleptinae). Folia entomologica hungarica, 58, 89-100.

Móczár, L (1998a ['1997']) Revision of the Cleptes (Holcocleptes) species of the world (Hymenoptera, Chrysididae). Acta Zoologica Academiae Scientiarum Hungaricae, 43 (4), 323-343.

Móczár, L. (1998b) Supplement to the revision of Cleptes (Leiocleptes) of the world (Hymenoptera: Chrysididae, Cleptinae). Folia entomologica hungarica, 59, 209-211.

Móczár, L. (1998c) Revision of the Cleptinae of the World. Genus Cleptes subgenera and species groups. (Hymenoptera, Chrysididae). Entomofauna, 19 (31), 501-516.

Móczár, L. (2000a) Revision of the Cleptes asianus and townesi groups of the world (Hymenoptera, Chrysididae, Cleptinae). Acta Zoologica Academiae Scientiarum Hungaricae, 46 (4), 319-331.

Móczár, L. (2000b) World revision of the Cleptes satoi group (Hymenoptera: Chrysididae, Cleptinae). Annales historico-naturales Musei nationalis hungarici, 92, 297-324.

Móczár, L. (2001) World revision of the Cleptes semiauratus group (Hymenoptera, Chrysididae, Cleptinae). Linzer biologische Beiträge, 33 (1), 905-931.

Móczár, L. (2009) Cleptes hungaricus sp. n. and the related Palaearctic species (Hymenoptera: Chrysididae). Annales Historico-Naturales Musei Nationalis Hungarici, 101, 131-136.

Özbek, H. \& Strumia, F. (2018) Research on the Subfamily Chrysidinae (Hymenoptera: Chrysididae) Fauna of Turkey with Distributional Evaluation. Acta Entomologica Serbica, 23 (2), 75-104.

Pourrafei, L., Lotfalizadeh, H., Shayesteh-Far, A. \& Ramezani, M. (2011) Cuckoo wasps of the subfamily Chrysidinae (Hymenoptera: Chrysididae) in the north-west of Iran. Applied Entomology and Phytopathology, 79 (1), 87-116.

Rosa, P. (2020). New records of Chrysididae from Iran (Hymenoptera). ). Linzer Biologische Beiträge, 52 (1), 461-474.

Rosa, P., Belokobylskij, S.A. \& Zaytseva, L.A. (2017) The Chrysididae types described by SemenovTian-Shanskij and deposited at The Zoological Institute of The Russian Academy of Sciences, Saint Petersburg (Insecta: Hymenoptera). Proceedings of the Zoological Institute RAS, Supplement No 5, 266 pp.

Rosa, P. \& Lotfalizadeh, H. (2013) A new species-group of Chrysura Dahlbom, 1845 (Hymenoptera: Chrysididae), with description of Ch. baiocchii sp. nov. from Iran. Zootaxa, 3737, 24-32. http://dx.doi.org/10.11646/zootaxa.3737.1.2

Rosa, P., Gadallah, N.S. \& Brothers, D.J. (2020) Biodiversity of the aculeate wasps (Hymenoptera: Aculeata) of the Arabian Peninsula: Chrysidoidea, Chrysididae. Zootaxa, 4754 (1), 92-101. https://doi.org/10.11646/zootaxa.4754.1.10

Rosa, P., Lotfalizadeh, H. \& Pourrafei, L. (2013) First checklist of the chrysidid wasps (Hymenoptera: Chrysididae) of Iran. Zootaxa, 3700 (1), 1-47. http:// dx.doi.org/10.11646/zootaxa.3700.1.1 
Rosa, P., Forshage, M., Paukkunen, J., \& Soon, V. (2015) Cleptes pallipes Lepeletier synonym of Cleptes semiauratus (Linnaeus) and description of Cleptes striatipleuris sp. nov. (Hymenoptera: Chrysididae, Cleptinae). Zootaxa, 4039 (4), 543-552. http:// dx.doi.org/10.11646/zootaxa.4039.4.4

Rosa, P., Wei, N-s., Feng, J., \& Xu, Z-f (2016) Revision of the genus Trichrysis Lichtenstein, 1876 from China, with description of three new species (Hymenoptera, Chrysididae). Deutsche Entomologische Zeitschrift, 63(1), 109-136. http://dx.doi.org/10.3897/dez.63.7347

Rosa, P., Lelej, A.S., Belokobylskij, S.A., Vinokurov, N.B. \& Zaytseva, L.A. (2019) Illustrated and annotated check-list of the Russian cuckoo wasps (Hymenoptera, Chrysididae). Entomofauna, Supplement 23, 1-360. https:// doi.org/10.25221/fee.360.1

Strumia, F. (2008) Order Hymenoptera, Family Chrysididae. In: van Harten, A. (ed.). Arthropod Fauna of the U.A.E. vol. 1, Dar Al Ummah Printing, Abu Dabi, pp. 375-387.

Strumia, F. (2009). Trichrysis baratzsensis sp. nov. (Hymenoptera: Chrysididae) from Sardinia. Zootaxa, 2318, 589-595. https://doi.org/10.11646/zootaxa.2318.1.25

Strumia, F. (2014) Order Hymenoptera, family Chrysididae. Upgraded checklist of the Chrysididae from the U.A.E. In: van Harten, A. (ed.). Arthropod fauna of the U.A.E. vol. 5, Dar Al Ummah Printing, Abu Dabi, pp. 471-504.

Strumia, F. \& Dawah, H. (2010 [“2008-2009”]) Contribution to the knowledge of Chrysididae of Saudi Arabia (Hymenoptera, Aculeata). Frustula Entomologica, New Series, 31 (44), 1-10.

Strumia, F. \& Dawah, H. (2012 [“2010-2011”]) New Hymenoptera Chrysididae from South Western Saudi Arabia. Frustula Entomologica, New Series, 33 (46), 171-179.

Strumia, F. \& Dawah, H. (2019) An overview of the Chrysididae (Hymenoptera) of the Red Sea Farasan Archipelago (Saudi Arabia). Journal of Insect Biodiversity, 9 (1), 1-17. https://doi.org/10.12976/jib/2019.09.1.1

Strumia, F. \& Fallahzadeh, M. (2015) New records and three new species of Chrysididae (Hymenoptera, Chrysidoidea) from Iran. Journal of Insect Biodiversity, 3 (15), 1-32. https://doi.org/10.12976/jib/2015.3.15

Strumia, F. \& Fallahzadeh, M. (2016) A new species of the genus Haba Semenov, 1954 (Hymenoptera, Chrysididae) from Iran with a key to species. Zoology in the Middle East, 26 (4), 358-362. http://dx.doi.org/10.1080/09397140.2016.1250858

Strumia, F., Fallahzadeh, M. \& Izadi, E. (2016a) Chrysura izadiae sp. nov., a new cuckoo wasp (Hymenoptera, Chrysididae) from Southern Iran. Zootaxa, 4061, 281-285. http://doi.org/10.11646/zootaxa.4061.3.7

Strumia, F., Fallahzadeh, M., Izadi, E. \& Tavassoli, H. (2016b) Additions to the tribe Elampini (Hymenoptera, Chrysididae) of southern Iran, with description of a new subspecies. Trends in Entomology, 12, 51- 61.

Torabipour, Sh., Ebrahimi, E., Lotfalizadeh, H. \& Rosa, P. (2013a) New records of two species of the genus Pentachrysis Lichtenstein (Hym.: Chrysididae) in Iran. Applied Entomology and Phytopathology, 81 (1), 85-86.

Torabipour, Sh., Ebrahimi, E., Lotfalizadeh, H. \& Rosa, P. (2013b). Faunstic study of tribe Elampini (Hym.: Chrysididae) in Hayk Mirzayans Insect Museum (HMIM), Iran. Field Crop Entomology, 2 (1), 1-14. 


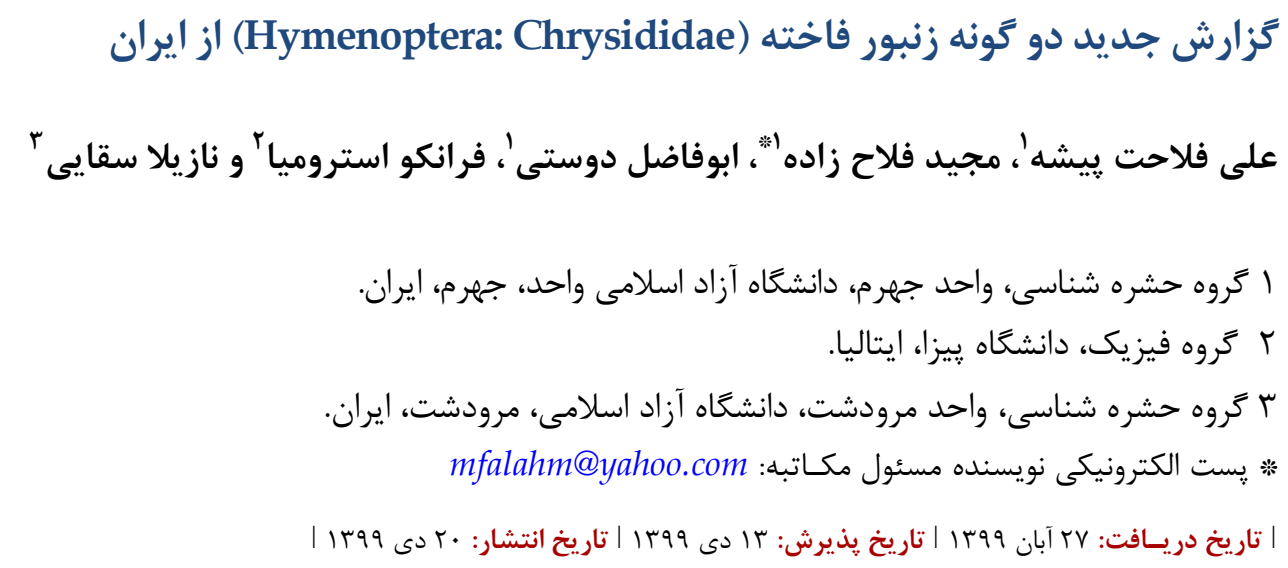

جكيـده: در مطالعه حاضر، دو گونه زنبور فاخته (Hymenoptera: Chrysididae)

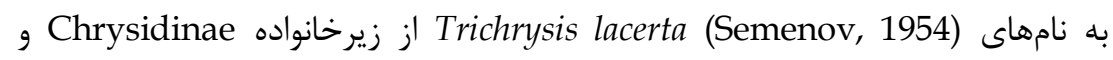
Cleptes striatipleuris Rosa, Forshage, Paukkunen \& Soon, 2015 خانواده Cleptinae براى اولين بار از ايران گزارش مىشوند. نمونها با استفاده از تله

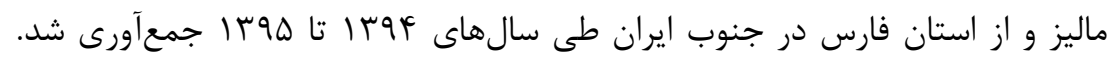

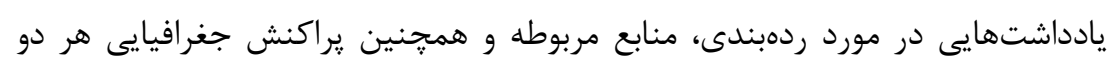

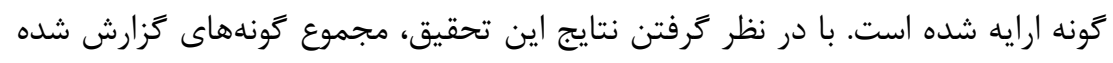

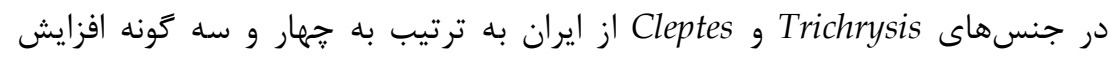
يافت. وازَّــان كليدى: زنبورهاى فاخته، Chrysidinae، Cleptinae، بال غشاييان، گزارش جديد 